\title{
Predictions of Hypoxic-Ischemic Encephalopathy by Umbilical Cord Blood Lactate in Newborns with Birth Asphyxia
}

\author{
Ton Nu Van Anh ${ }^{1}$, Tran Kiem Hao ${ }^{2 *}$, Nguyen Thi Diem $\mathrm{Chi}^{2}$, Nguyen Huu Son ${ }^{2}$ \\ ${ }^{1}$ Pediatric Department, Hue University of Medicine and Pharmacy, Hue University, Hue, Vietnam; ${ }^{2}$ Pediatric Center, Hue \\ Central Hospital, Hue, Vietnam
}

\begin{abstract}
Citation: Van Anh TN, Kiem Hao T, Diem Chi NT, Huu Son N. Predictions of Hypoxic-Ischemic Encephalopathy by Umbilical Cord Blood Lactate in Newborns with Bir Asphyxia. Open Access Maced J Med Sci. 2019 Nov 15;

/10.3889/oamjms.2019.58

Keywords: Hypoxic ischemic encephalopathy; Asphyxia; Umbilical cord; Lactate

*Correspondence: Tran Kiem Hao. Pediatric Center, Hue Central Hospital. 16 Le Loi street, Hue city, Vietnam. Phone Humber: +84914002329. h/ps//orid.org/0000Received: 28-Apr-2019; Revised: 04-Sep-2019 Accepted: 05-Sep-2019; Online first: 13-Oct-2019 Copyright: ๑ 2019 Ton Nu Van Anh, Tran Kiem Hao, Nguyen Thi Diem Chi, Nguyen Huu Son. This is an openaccess article distributed under the terms of the Creative Commons Attribution-NonCommercial 4.0 Internationa

Funding: This research did not receive any financia support

Competing Interests: The authors have declared that no competing interests exis
\end{abstract}

\section{Abstract}

AIM: The aim of the study was to investigate the role of umbilical cord blood lactate as early predictors of hypoxic ischemic encephalopathy in newborns with perinatal asphyxia and to evaluate their sensitivity and specificity for the early identification of hypoxic ischemic encephalopathy infants.

METHODS: We performed a descriptive cross sectional study between April 2014 and April 2015 at Hue Central Hospital, Vietnam. 41 asphyxia newborns (Apgar score $\leq 7$ ) were included in the study. Umbilical cord blood is sampled for lactate analysis.

RESULTS: Umbilical cord blood lactate levels were significantly higher among infants born with HIE (mean $8.72 \pm$ 1.75 , range 5.12 - 11.96) compared to that with asphyxic infants without HIE (mean $6.86 \pm 1.33$, range 4.74 $10.30), p=0.00$. With the optimal cutoff point for umbilical cord blood lactate level of $8.12 \mathrm{mmol} / \mathrm{l}$ to susspected of HIE (area under the curve 0.799$)$ had a sensitivity $73.7 \%(95 \% \mathrm{Cl}: 48.8-90.9)$, specificity $86.4 \%(95 \% \mathrm{Cl}$ : 65.1 . 97.1).

CONCLUSION: Umbilical cord blood lactate could be used as early predictors in diagnosis of hypoxic ischemic encephalopathy in newborns with asphyxia.

\section{Introduction}

Hypoxic ischemic encephalopathy (HIE) is one of the most serious birth complications affecting full term infants [1]. It occurs in 1.5 to 2.5 per 1000 live births in developed countries. HIE is a brain injury that prevents adequate blood flow to the infant's brain occurring as a result of a hypoxic-ischemic event during the prenatal, intrapartum or postnatal period [2], [3]. By the age of 2 years, up to $60 \%$ of infants with HIE will die or have severe disabilities including mental retardation, epilepsy, and cerebral palsy (CP) [2], [4], [5], [6], [7]. The early prediction of hypoxic ischemic encephalopathy is particularly important because of the brief thera-peutic window and possible side effects of neuro protective interventions [8].

Several biomarkers were done for proper assessment of the severity of brain damage. An ideal biomarker for the diagnosis of HIE should be specific, early, rapid, and easily done. The results of these biomarkers should be interpreted in conjunction with the clinical history and physical examination [9], [10].

Lactate is invariably produced in the event of hypoxia and poor tissue perfusion. When a clinical reduction of oxygen and substrate delivery occurs, aerobic metabolism through Krebs cycle cannot be sustained and tissues need anaerobic metabolism to meet the energy requirement. This in turn leads to increase in the production and accumulation of blood lactate [11]. Lactate is produced by anerobic oxidation during an asphyxia insult and continues to be excreted via the kidney for a long period after the insult so that measurement of urinary lactate may reflect the blood lactate level and the degree of metabolic derangement as a result of hypoxia/ischemia [12].

The aim of the study was to investigate the 
role of umbilical cord blood lactate as early predictors of HIE in Newborns with Perinatal Asphyxia and to evaluate their sensitivity and specificity for the early identification of HIE infants.

\section{Patients and Methods}

\section{Patients}

A prospective study including 41 infants with a proven diagnosis of asphyxia who were admitted to neonatal intensive care unit (NICU) in Hue Central Hospital, Vietnam, from April 2014 to April 2015. Apgar score at 1 minute after birth was used to identify perinatal asphyxia in the new born. Those babies with apgar score of $\leq 7$ were considered to have had perinatal asphyxial insult.

The asphyxia newborns were categorized into two groups according to the presence of HIE. Suspect neonatal HIE in the baby who is asphyxia at birth and who, in the earliest hours of life, presents with disturbed neurological function including [13]:

- A subnormal level of consciousness or seizures.

- And frequently:

respiration.

+ Difficulty initiating and maintaining

+ Depression of tone and reflexes.

Exclusion Criteria: 1) Newborn delivered with major congenital anomalies or chromosomal abnormality and 2) Multiple pregnancies.

\section{Measurements}

Umbilical cord blood is sampled by nursing personnel immediately after delivery for all infants deemed to be viable. Umbilical blood samples were drawn from a double-clamped segment of the umbilical cord into $2 \mathrm{ml}$ plastic syringes flushed with a heparin solution. Blood lactate were measured using whole blood in automated benchtop analyzers. The DXC-800 Automated Chemistry Analyser (Beckman Coulter) was used for lactate assays. Obtained data was recorded in a newborn's notes.

\section{Data analysis}

We first selected a range of cutoff points for the umbilical cord lactate biomarker to distinguish HIE from asphyxic newborn without HIE. We reported the sensitivity, specificity and negative predictive value (NPV) for HIE of each lactate cutoff point. Next, we generated a receiver-operator curve (ROC) to visually represent the trade-off between sensitivity and specificity. We utilized ROC curve analysis to select the optimal lactate cutoff point to minimize both the number of false positives. A Mann-Whitney U-test was performed to compare lactate levels between children with HIE and without HIE. We used SPSS version 19.0 for all statistical analyses.

\section{Results}

41 asphyxia newborns with singleton, liveborn infants with no major anomalies delivering between April 2015 to April 2016 were analysed. Gestational age ranged from 35 to 41 weeks (mean $37.41 \pm 0.31$ weeks). Umbilical cord blood lactate levels were significantly higher among infants born with HIE (mean $8.72 \pm 1.75$, range $5.12-11.96$ ) compared to that with asphyxic infants without HIE (mean $6.86 \pm$ 1.33 , range $4.74-10.30), p=0.001$ (Table 1 ).

Table 1: Umbilical cord blood lactate level in asphyxic newborns with and without HIE

\begin{tabular}{lcc}
\hline & $\begin{array}{c}\text { Non-HIE } \\
(\mathrm{n}=22)\end{array}$ & $\begin{array}{c}\mathrm{HIE} \\
(\mathrm{n}=19)\end{array}$ \\
\hline Mean lactate, $\mathrm{mmol} / \mathrm{l}$ & 6.86 & 8.72 \\
$(\mathrm{SD})$ & $( \pm 1.33)$ & $( \pm 1.75)$ \\
Median lactate, $\mathrm{mmol} / \mathrm{l}$ & 6.60 & 8.88 \\
(interquartile range) & $(5.99-7.70)$ & $(8.05-9.84)$ \\
\hline
\end{tabular}

Each step-wise increase in the umbilical cord blood lactate level cutoff point lowered the sensitivity, but increased the specificity for HIE (Table 2). Next we present a ROC curve for umbilical cord blood lactate level for HIE (Figure 1).

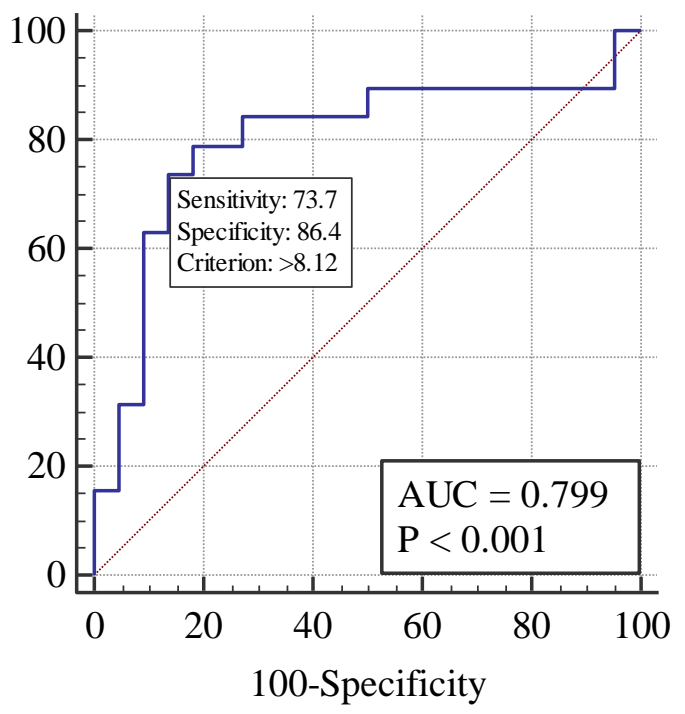

Figure 1: Receiver-operating curve for lactate to distinguish HIE from asphyxic newborn without HIE. Overall accuracy was good, with area under ROC curve of 0.799 (95\% Cl: $0.645-0.908), p=$ 0.0001

Using ROC analysis, we selected an optimal cutoff point for umbilical cord blood lactate level of 
$8.12 \mathrm{mmol} / \mathrm{l}$ to susspected of HIE (area under the curve 0.799). Umbilical cord blood lactate level $\geq 8.12$ $\mathrm{mmol} / / \mathrm{l}$ had a sensitivity $73.7 \%(95 \% \mathrm{Cl}$ : 48.8-90.9), specificity $86.4 \% \quad(95 \% \quad \mathrm{Cl}: 65.1-97.1)$, +ve LR (likelihood ratio) 5.4, -ve LR 0.3 for HIE (Table 2).

Table 2: The diagnosis accuracy of Umbilical Cord Blood Lactate for HIE by cutoff point

\begin{tabular}{lcccccc}
\hline Criterion & Sensitivity & $95 \% \mathrm{Cl}$ & Specificity & $95 \% \mathrm{Cl}$ & $+\mathrm{LR}$ & -LR \\
\hline$\geq 4.74$ & 100.00 & $82.4-100.0$ & 0.00 & $0.0-15.4$ & 1.00 & \\
$>4.74$ & 100.00 & $82.4-100.0$ & 4.55 & $0.1-22.8$ & 1.05 & 0.00 \\
$>5.31$ & 89.47 & $66.9-98.7$ & 4.55 & $0.1-22.8$ & 0.94 & 2.32 \\
$>6.48$ & 89.47 & $66.9-98.7$ & 50.00 & $28.2-71.8$ & 1.79 & 0.21 \\
$>6.67$ & 84.21 & $60.4-96.6$ & 50.00 & $28.2-71.8$ & 1.68 & 0.32 \\
$>7.12$ & 84.21 & $60.4-96.6$ & 72.73 & $49.8-89.3$ & 3.09 & 0.22 \\
$>7.36$ & 78.95 & $54.4-93.9$ & 72.73 & $49.8-89.3$ & 2.89 & 0.29 \\
$>7.89$ & 78.95 & $54.4-93.9$ & 81.82 & $59.7-94.8$ & 4.34 & 0.26 \\
$>8.02$ & 73.68 & $48.8-90.9$ & 81.82 & $59.7-94.8$ & 4.05 & 0.32 \\
$>8.12$ & 73.68 & $48.8-90.9$ & 86.36 & $65.1-97.1$ & 5.40 & 0.30 \\
$>8.28$ & 63.16 & $38.4-83.7$ & 86.36 & $65.1-97.1$ & 4.63 & 0.43 \\
$>8.29$ & 63.16 & $38.4-83.7$ & 90.91 & $70.8-98.9$ & 6.95 & 0.41 \\
$>9.18$ & 31.58 & $12.6-56.6$ & 90.91 & $70.8-98.9$ & 3.47 & 0.75 \\
$>9.27$ & 31.58 & $12.6-56.6$ & 95.45 & $77.2-99.9$ & 6.95 & 0.72 \\
$>9.88$ & 15.79 & $3.4-39.6$ & 95.45 & $77.2-99.9$ & 3.47 & 0.88 \\
$>10.3$ & 15.79 & $3.4-39.6$ & 100.00 & $84.6-100.0$ & & 0.84 \\
$>11.96$ & 0.00 & $0.0-17.6$ & 100.00 & $84.6-100.0$ & & 1.00 \\
\hline
\end{tabular}

\section{Discussion}

Perinatal hypoxic-ischemic encephalopathy (HIE) occurs in one to three per 1000 live full-term births [14]. Of affected newborns, $15 \%-20 \%$ of affected newborns will die in the postnatal period, and an additional $25 \%$ will develop severe and permanent neuropsychological sequelae, including mental retardation, visual motor or visual perceptive dysfunction, increased hyperactivity, cerebral palsy, and epilepsy [15]. The outcomes of HIE are devastating and permanent, making it a major burden for the patient, the family, and society.

The early prediction of hypoxic ischemic encephalopathy is particularly important because of the brief therapeutic window and possible side effects of neuro protective interventions [16], [17]. In spite of major advances with sophisticated monitoring technology and knowledge of fetal and neonatal pathology, perinatal asphyxia or more appropriately, HIE remains a serious condition, that leaves a significant handicaps in the survivors [18].

In our study the mean of serum lactate level in HIE group was $8.21 \mathrm{mmol} / \mathrm{L}$ while in the non-HIE group the level of lactate was $6.86 \mathrm{mmol} / \mathrm{dl}$ which was statistically significant as $p$ value $=0.001$. This in agreement with some studies who found that serum lactate was higher in hypoxic group than healthy group. Mohamed Shawky Elfarargy et al., study nucleated red blood cells per 100 white blood cell (NRBC/100 WBC) counts and lactate levels in cord blood as early markers of neonatal HIE, the median of serum lactate level in hypoxic group was $7 \mathrm{mmol} / \mathrm{L}$ while in the control group the level of lactate was 1.9 $\mathrm{mmol} / \mathrm{dl}$ which was statistically significant as $p$ value < 0.0001 , and the more grade of HIE the higher serum lactate [19]. Shah et al., [12] carried out a study on 61 term neonates to estimate lactate level as a predictor for short term outcome after intrapartum asphyxia. They found that the median of lactate level 11.09 $\mathrm{mmol} / \mathrm{dl}$ in asphyxi-ated group met all the criteria of hypoxic ischemic encephalopathy, the study also found that plasma lactate levels lower than $5 \mathrm{mmol} / \mathrm{dl}$ were not asso-ciated with severe encephalopathy while plasma lactate levels $>15 \mathrm{mmol} / \mathrm{L}$ were associated with moderate to severe HIE in $100 \%$ of cases. As in hypoxic patients, a critical reduction in oxygen substrate delivery occurs, aerobic metabolism through Kreb's cycle cannot be sustained, and tissues need anaerobic metabolism to meet their energy requirements. This in turn leads to an in-crease in the production and accumulation of blood lactate [20]. In other study done by Zhang Haiju et al., [8], carried out on 46 asphyxiated new newborns, the level of serum lactate in umbilical cord blood in the first six hours after delivery was $4.3 \pm 1.2 \mathrm{SD}$ while in control group, the median of serum lactate was $2.46 \pm 0.48 \mathrm{mmol} / \mathrm{dl}$. Many factors may exist that could influence the results, such as the different inclusion criteria, different races and lifestyle.

In our study umbilical cord blood lactate level to diagnose HIE was $>8.12 \mathrm{mmol} / \mathrm{L}$ which yield a sensitivity of $73.7 \%$, specificity $86.4 \%$. Overall accuracy was good, with area under ROC curve of 0.799 (95\% Cl: $0.645-0.908), p=0.0001$. This is in agreement with some studies which concluded that Umbilical lactate can be used in a middle-low resource setting as a measurement of intrapartum hypoxia, with reasonable sensitivity and specificity. Mohamed Shawky Elfarargy et al reported that serum lactate level to diagnose HIE was $>3.6 \mathrm{mmol} / \mathrm{L}$ which yield a sensitivity of $87 \%$, specificity $100 \%$, PPV $100 \%$ and NPV $88 \%$ with a diagnostic accuracy of $93 \%$. Allanson ER et al., from 3 March-12 November 2014, conducted a prospective cohort study of UA lactate levels at Kalafong Hospital, Pretoria, South Africa. A lactate was recorded for 946 deliveries (20.3\%). One hundred ninety babies required neonatal resuscitation, with an optimal cutoff for lactate of $5.45 \mathrm{mmol} / \mathrm{L}$ (sensitivity $68 \%$, specificity $72 \%$ ). 124 babies required nursery admission with the optimal cutoff for lactate $4.95 \mathrm{mmol} / \mathrm{L}$ (sensitivity $61 \%$, specificity $59 \%$ ) [21]. According to Simovic A, significantly higher concentrations of lactate (p $8.7 \mathrm{mmol} / \mathrm{L}$ with $80 \%$ sensitivity and $82 \%$ specificity indicated the development of the hypoxic-ischemic encephalopathy stage II/III, while the lactate level $>9.95 \mathrm{mmol} / \mathrm{L}$ was a predictor of death, with $75 \%$ sensitivity and $74.4 \%$ specificity [22]. Vannucci et al., [23], who showed that, the best cut off of lactate in predicting HIE was 4.25 $\mathrm{mmol} / \mathrm{L}$ with sensitivity of $94 \%$ and specificity of $86 \%$. In previous studies, it was shown that lactate concentration in the term newborns which is in first 24 hours $>7.5 \mathrm{mmol} / \mathrm{l}$ with $94 \%$ sensitivity and $67 \%$ specifi city may indicate the development of the HIE and that an early increase in lactate in severe asphyxia $>15 \mathrm{mmol} / \mathrm{l}$ was a sure indication of serious consequences or death with $100 \%$ sensitivity of and 
$88 \%$ specificity [12], [20], [24].

In conclusion, umbilical cord blood lactate could be used as early predictors in diagnosis of hypoxic ischemic encephalopathy being very easy, cheap and non-invasive measure. Combined Apgar score and umbilical cord blood lactate in diagnosis of HIE gives us better sensitivity and specificity than lactate alone, also it could be used in prognosis of the newborns with hypoxic ischemic encephalopathy and for detecting the outcome.

\section{Ethics Approval and Consent to Participate}

The present study was approved by the Hue Central Hospital Ethical Committee. Informed consent was waived. Consent for publication Not applicable.

\section{References}

1. Schiariti V, Klassen AF, Hoube JS, Synnes A, Lisonkova S, Lee SK. Perinatal characteristics and parents' perspective of health status of NICU graduates born at term. J Perinatol. 2008; 28(5):368-76. https://doi.org/10.1038/ip.2008.9 PMid:18288117

2. Long M, Brandon DH. Induced hypothermia for neonates with hypoxic-ischemic encephalopathy. J Obstet Gynecol Neonatal Nurs. 2007; 36(3):293-8. https://doi.org/10.1111//.1552-6909.2007.00150.x PMid: 17489937

3. Wintermark P, Labrecque M, Warfield SK, DeHart S, Hansen A. Can induced hypothermia be assured during brain MRI in neonates with hypoxic-ischemic encephalopathy? Pediatr Radiol. 2010; 40(12):1950 4. https://doi.org/10.1007/s00247-010-1816-2 PMid:20737144 PMCid:PMC3335293

4. Hoehn T, Hansmann G, Buhrer C, Simbruner G, Gunn AJ, Yager J, Levene M, Hamrick SE, Shankaran S, Thoresen M. Therapeutic hypothermia in neonates. Review of current clinical data, ILCOR recommendations and suggestions for implementation in neonatal intensive care units. Resuscitation. 2008; 78(1):7-12. https://doi.org/10.1016/j.resuscitation.2008.04.027 PMid:18554560

5. Okereafor A, Allsop J, Counsell SJ, Fitzpatrick J, Azzopardi D, Rutherford MA, Cowan FM. Patterns of brain injury in neonates exposed to perinatal sentinel events. Pediatrics. 2008; 121(5):906-14. https://doi.org/10.1542/peds.2007-0770 PMid:18450893

6. Pierrat V, Haouari N, Liska A, Thomas D, Subtil D, Truffert P, Groupe d'Etudes en Epidemiologie P. Prevalence, causes, and outcome at 2 years of age of newborn encephalopathy: population based study. Arch Dis Child Fetal Neonatal Ed. 2005; 90(3):F257-61. https://doi.org/10.1136/adc.2003.047985 PMid:15846019 PMCid:PMC1721886

7. Zhou WH, Cheng GQ, Shao XM, Liu XZ, Shan RB, Zhuang DY, Zhou CL, Du LZ, Cao Y, Yang Q, Wang LS, China Study G. Selective head cooling with mild systemic hypothermia after neonatal hypoxic-ischemic encephalopathy: a multicenter randomized controlled trial in China. $J$ Pediatr. 2010; 157(3):367-72; 372 e1-3.

https://doi.org/10.1016/j.jpeds.2010.03.030 PMid:20488453

8. Haiju Z, Suyuan H, Xiufang F, Lu Y, Sun R. The combined detection of umbilical cord nucleated red blood cells and lactate: early prediction of neonatal hypoxic ischemic encephalopathy. J Perinat Med. 2008; 36(3):240-7. https://doi.org/10.1515/JPM.2008.035 PMid:18576934

9. Jones R, Heep A, Odd D. Biochemical and clinical predictors of hypoxic-ischemic encephalopathy after perinatal asphyxia. J Matern Fetal Neonatal Med. 2018; 31(6):791-796.

https://doi.org/10.1080/14767058.2017.1297790 PMid:28274150

10. Shankaran S, Laptook AR, McDonald SA, Hintz SR, Barnes PD, Das A, Higgins RD. Eunice Kennedy Shriver National Institute of Child $\mathrm{H}$, and Human Development Neonatal Research N. Acute Perinatal Sentinel Events, Neonatal Brain Injury Pattern, and Outcome of Infants Undergoing a Trial of Hypothermia for Neonatal Hypoxic-Ischemic Encephalopathy. J Pediatr. 2017; 180:275-278 e2. https://doi.org/10.1016/i.jpeds.2016.09.026 PMid:27776752 PMCid:PMC5183477

11. Jin ES, Sherry AD, Malloy CR. Metabolism of glycerol, glucose, and lactate in the citric acid cycle prior to incorporation into hepatic acylglycerols. J Biol Chem. 2013; 288(20):14488-96. https://doi.org/10.1074/ibc.M113.461947 PMid:23572519 PMCid:PMC3656303

12. Shah S, Tracy M, Smyth J. Postnatal lactate as an early predictor of short-term outcome after intrapartum asphyxia. J Perinatol. 2004; 24(1):16-20. https://doi.org/10.1038/si.jp.7211023 PMid:14726932

13. Amirhassani S, Mousavi-Bahar SH, lloon Kashkouli A, Torabian S. Comparison of the safety and efficacy of one-shot and telescopic metal dilatation in percutaneous nephrolithotomy: a randomized controlled trial. Urolithiasis. 2014; 42(3):269-73. https://doi.org/10.1007/s00240 014-0644-5 PMid:24531816

14. Graham EM, Ruis KA, Hartman AL, Northington FJ, Fox HE. A systematic review of the role of intrapartum hypoxia-ischemia in the causation of neonatal encephalopathy. Am J Obstet Gynecol. 2008; 199(6):587-95. https://doi.org/10.1016/.ajog.2008.06.094 PMid:19084096

15. Sherman MP. Interventions for perinatal hypoxic-ischemic encephalopathy. Pediatrics. 1998; 102(3 Pt 1):662. https://doi.org/10.1542/peds.102.3.662 PMid:9738198

16. Graham EM, Everett AD, Delpech JC, Northington FJ. Blood biomarkers for evaluation of perinatal encephalopathy: state of the art. Curr Opin Pediatr. 2018; 30(2):199-203.

https://doi.org/10.1097/MOP.0000000000000591 PMid:29346139 PMCid:PMC5884146

17. Guan B, Dai C, Zhang Y, Zhu L, He X, Wang N, Liu H. Early diagnosis and outcome prediction of neonatal hypoxic-ischemic encephalopathy with color Doppler ultrasound. Diagn Interv Imaging 2017; 98(6):469-475. https://doi.org/10.1016/j.diii.2016.12.001 PMid:28024912

18. Juul SE, Comstock BA, Heagerty PJ, Mayock DE, Goodman AM, Hauge S, Gonzalez F, Wu YW. High-Dose Erythropoietin for Asphyxia and Encephalopathy (HEAL): A Randomized Controlled Trial -

Background, Aims, and Study Protocol. Neonatology. 2018; 113(4):331338. https://doi.org/10.1159/000486820 PMid:29514165 PMCid:PMC5980685

19. Elfarargy MS, Elsharkawy HM. Study of Lactate and Nucleated Red Blood Cells as Early Predictors of Neonatal Hypoxic Ischemic Encephalopathy. Acta Scientific Paediatrics. 2018; 1(2):3-8.

20. da Silva S, Hennebert N, Denis R, Wayenberg JL. Clinical value of a single postnatal lactate measurement after intrapartum asphyxia. Acta Paediatr. 2000; 89(3):320-3. https://doi.org/10.1111/j.1651. 2227.2000.tb01334.x PMid:10772280

21. Allanson ER, Pattinson RC, Nathan EA, Dickinson JE. The introduction of umbilical cord lactate measurement and associated neonatal outcomes in a South African tertiary hospital labor ward. $J$ Matern Fetal Neonatal Med. 2018; 31(10):1272-1278. https://doi.org/10.1080/14767058.2017.1315094 PMid:28372476

22. Simovic A, Stojkovic A, Savic D, Milovanovic DR. Can a single lactate value predict adverse outcome in critically ill newborn? Bratis Lek Listy. 2015; 116(10):591-5. https://doi.org/10.4149/BLL 2015115 PMid:26531869

23. Vannucci RC, Perlman JM. Interventions for perinatal hypoxicischemic encephalopathy. Pediatrics. 1997; 100(6):1004-14. https://doi.org/10.1542/peds.100.6.1004 PMid:9374573

24. Chanrachakul B, Chua S, Nordstrom L, Yam J, Arulkumaran S. Umbilical artery blood gas and lactate in healthy newborns. J Med Assoc Thai. 1999; 82(4):388-93. 